\author{
ARTIGO \\ dO] https://doi.org/10.22481/praxisedu.v16i37.6171
}

\title{
TEACHING STRATEGIES METHODS AND TECHNIQUES USED BY PRE- SCHOOL TEACHER CANDIDATES
}

\author{
ESTRATEGIAS DE ENSEÑANZA MÉTODOS Y TÉCNICAS UTILIZADAS POR LOS \\ CANDIDATOS A MAESTROS DE PREESCOLAR
}

\author{
ESTRATÉGIAS DE ENSINO MÉTODOS E TÉCNICAS EMPREGADAS POLOS \\ CANDIDATOS DE PRE-ESCOLAR
}

\author{
Ipek Danju \\ Near East University - Turquia
}

Seçil Besim

Near East University - Turquia

\begin{abstract}
This research was conducted in order to determine the which strategies, methods and techniques used by the preschool teacher candidates who prefer to use in the classroom activities in Special Teaching Methods I and II course. The researchers aimed what kind of educational strategies, methods and techniques that the prospective preschool teacher candidates preferred to use in the course of their activities in the Special Teaching Methods. Qualitative research methodologies used for this research. Descriptive and content analyses were conducted in the qualitative dimension of this study. Descriptive analysis has been used in this qualitative dimension by taking direct quotations from the statements of participants in the analysis of descriptive data. This study has been carried out in Nicosia, Cyprus, in 2016 - 2017 academic year. Sample group 87 preschool teacher candidates voluntarily participated to this study. According to results of the study, it has been indicated that the preschool teacher candidates are using mostly classical teaching strategy, methods and techniques. However, preschool teacher candidates prefer to use contemporary teaching strategies, methods and techniques like drama.
\end{abstract}

Keywords: Special Teaching Method Course; Teaching Methods; Teaching Strategies; Teaching Techniques.

Resumen: Esta investigación se realizó para determinar las estrategias, métodos y técnicas utilizadas por los candidatos a maestros de preescolar que prefieren utilizar en las actividades de clase en el curso de Métodos de enseñanza especial I y II. Los investigadores apuntaron qué tipo de estrategias, métodos y técnicas educativas preferían utilizar los posibles candidatos a maestros de preescolar en el curso de sus actividades en los Métodos de enseñanza especial. Se utilizaron metodologías de investigación cualitativa para esta investigación. Se realizaron análisis descriptivos y de contenido en la dimensión 
cualitativa de este estudio. El análisis descriptivo se ha utilizado en esta dimensión cualitativa tomando citas directas de las declaraciones de los participantes en el análisis de datos descriptivos. Este estudio se llevó a cabo en Nicosia, Chipre, en el año académico 2016-2017. El grupo de muestra 87 candidatos a maestros de preescolar participaron voluntariamente en este estudio. Según los resultados del estudio, se ha indicado que los candidatos a maestros de preescolar están utilizando principalmente estrategias, métodos y técnicas de enseñanza clásica. Sin embargo, los candidatos a maestros de preescolar prefieren usar estrategias, métodos y técnicas de enseñanza contemporáneas como el drama.

Palabras clave: Curso de método de enseñanza especial; Métodos de enseñanza; Estrategias de enseñanza; Técnicas de enseñanza.

Resumo: Esta pesquisa foi conduzida para determinar as estratégias, métodos e técnicas utilizadas pelos candidatos a professores de pré-escola que preferem usar em atividades de classe no curso Métodos Especiais de Ensino I e II. Os pesquisadores observaram que tipo de estratégias, métodos e técnicas educacionais os candidatos a professor em idade pré-escolar preferiram usar no curso de suas atividades nos Métodos Especiais de Ensino. Foram utilizadas metodologias de pesquisa qualitativa na realização desta pesquisa. A análise descritiva foi utilizada na dimensão qualitativa, através de citações diretas das falas dos participantes na análise dos dados descritivos. Este estudo foi realizado em Nicósia, Chipre, no ano letivo de 2016-2017. Um grupo de 87 candidatos a professores de pré-escola participou voluntariamente deste estudo. De acordo com os resultados do estudo, foi indicado que os candidatos a professores de pré-escola utilizam principalmente estratégias, métodos e técnicas clássicas de ensino. No entanto, os candidatos a professores de pré-escola preferem usar estratégias, métodos e técnicas contemporâneas de ensino, como o drama.

Palavras-chave: Curso especial de método de ensino; Métodos de ensino; Estratégias de ensino; Técnicas de ensino.

\section{Introduction}

The $21^{\text {st }}$ century pre-school teachers are expected to be a good guide who knows the learning-teaching processes well, observes the students, and is constantly changing and developing. For this reason, the teaching profession especially pre-school teaching is considered to be a profession that requires more qualification in order to have these characteristics (Marbach, Seal \& Sokolove 2001; Covill, 2011). The effectiveness of the teaching-learning process in the classroom is directly proportional to the selection of appropriate teaching methods and techniques. Açıkgöz (1998) the strategies used by the teachers will help to ensure their continuous professional development and will have an important role in increasing their social productivity. Öztürk (1996) examined the use of teaching strategies by university students. Prospective teachers' conscious use of teaching strategies has emerged as a result of their research. 
According to the structure of the classroom according to the teaching methods and techniques that teachers will use effectively, it is thought that the determination of lower threshold high limit concepts will enable them to practice their profession with a developmentoriented approach (Kahyaoğlu \& Yangın, 2007). From this point of view, it is emphasized that the method that should be emphasized and preferred the most in the educational environment is active teaching methods. It is also important to note that the qualifications that can be gained with pedagogical courses such as special teaching method course that in teacher training programs are necessary and important factors for the training of qualified individuals (Tütüncü, 2008). In order to achieve these objectives, theoretical knowledge should be presented in some areas. In addition to theoretical knowledge in some areas, laboratory applications, workshops or skill activities may be required (Aksu \& Doğan, 2015). Lectures, question-answer, discussion, problem solving, role, brainstorming, sightseeing-observation, group work, project, six-hat method, show-off method and drama method are frequently used methods under the framework of special teaching methods (Özden, 2000; Saban 2004). When pre-school teacher candidates were asked the most preferred methods and techniques within the scope of special teaching methods course, "drama came to the forefront with both the method and the technique, and it was emphasized that the drama allowed the student to activate the spontaneous functioning of the drama.

With the drama technique, it is pointed out that students can improve their problem solving and communication skills while learning how to behave in which situations. The most important of the benefits to be obtained by performing all stages of the method in a controlled manner (Özden, 2000); The difficulty in the narration is to make it easier to express the relatively abstract subjects and to develop their self-confidence and to develop themselves through different roles. Drama is defined as the act of meaning by certain people rather than random people doing something by chance. It includes all activities that involve action within drama. These activities include individuals 'communication with each other, individuals' communication with different objects and actions that arise as a result of reactions (Bulut \& ve Aktepe, 2015; Ulubey \& Toraman, 2015). Uşaklı (2014) emphasizes that there are two basic elements of drama. One of them is human and the other is action. In other words, drama describes the people in action. San (1990) emphasized the concept of play in drama and considered play as the main element of creative drama. San (1990) also emphasizes that one of the most important goals of creative drama is social learning and socialization. 
In this research, it is aimed to determine which pre-school teacher candidates who preference of teaching strategies, teaching methods and teaching techniques they learned in special teaching methods courses. For this purpose, the response to the following sub-problem is sought. Which teaching strategies, methods and techniques do preschool teachers prefer?

Educational Strategy.

According to the results of research on educational strategies and school curricula published in 2015 in the journal Educational Psychology, these mental exercises are not sufficient for math educators.

These students need more practice and more sophisticated teaching strategies to strengthen their minds and abilities in mathematics.

Fuchs developed one of the instructional strategies that the brain implements and can be empowered to implement when performing math exercises.

This method was designed for high school students at risk of mathematical problems.

By applying this educational strategy, students will be able to divide a large problem into smaller problems and then solve smaller problems.

The purpose of applying these multiple educational strategies is to prevent younger students from becoming involved in mathematics problems. Researchers are planning to implement this approach in Nashville school classrooms this year and thus evaluate the effectiveness of these educational strategies.

\section{A) Educational goals}

Nurturing thoughtful, creative and researching students

Exploitation of new technologies in education

Increase the motivation and depth of learning and teaching

Provide a variety of training methods for different talents and interests

To empower students to apply and acquire science 
Students are more interested in the classroom, the school and the classroom, and thus the science promotion

Providing a suitable and beneficial learning environment for learning

B) Teaching students

Teaching students

1) IT and IT

Today, information technology is used as one of the methods of knowledge transfer, with the introduction of information technology tools in schools providing the ground for students to enter the age of communication. Given the educational goals of elementary school and the importance of learning IT, computer education is one of the main lessons in the students' curriculum.

2) Strengthen the scientific vigor

Strong efforts and scientific and practical activities to enhance the students' academic ability and learning abilities are among the educational achievements of Shamat Atrat Primary School. Conducting vigorous teaching classes by prominent instructors, along with continuous exams, have led students to So that they are on the path to growing their talent and always being scientifically superior to their peers.

\section{3) English language in Primary School}

The key to communicating with today's world is knowing English, teaching English at Primary School as one of the primary lessons from pre-school to elementary school and continuing through elementary school. The use of specialist instructors and many years of experience in the field have enabled students to gain a high level of academic knowledge in English. 
4) Multimedia training

In Multimedia Teaching In addition to the usual teacher training, the teacher uses multimedia teaching materials including film, photography, sound, and more. Primary School, using innovative multimedia teaching methods along with the creativity of the instructors, has been able to deliver outstanding teaching features such as: creating an attractive and enjoyable teaching environment, reducing the time required to teach various topics, and long-term sustainability of teaching materials. Given, achieve.

\section{5) Specialized sport}

Due to the importance of exercise in the development and health of children, Primary School has taken special actions for the weekly exercise classes of students.

Transfer students to the gym during sports hours

Gymnastics training by specialist trainers for first and second graders

Classification of third and fourth and fifth grade students according to their interest

Providing enough sports equipment for all sports

Holding sports competitions among students at the stadium

C) Teacher training

Teacher training

Teaching and teaching in today's world is a very professional job because every year the teacher comes in contact with new students and new models and needs to correctly identify their needs and competencies, The guiding and principled role of the teacher in the teaching process is the important and essential factor for accurate and efficient teacher education. Examples of teachers' training at Primary School include IT skills, curriculum, teaching methods, encouragement and evaluation of students, etc. Teacher training along with continuous assessment of their performance is one of the prominent factors of teachers' performance level in Primary School. 
D) Parent education

Parent training

Parents of students play a key role in the balanced and comprehensive development of students and are considered as educational resources. Increasing parental involvement in educational processes is one of the top priorities in Primary School. General programs for parent education of students can be She pointed to IT courses, training sessions on educational needs, guidance, motivation and counseling for children, setting up a dedicated parent library, and more.

\section{Breeding strategy}

A) Communication with students

\section{Counseling Center}

The most useful tools and strategies for student growth are person-to-person planning with supervised counselors and parents. Counseling helps people develop their knowledge and skills in problem solving and decision making, helping them overcome their problems and choosing the best of the different solutions. Helping parents play an effective role in raising children And helping to develop the personality of all students and develop their talents and skills, by planning and delivering individual counseling for parents and students, holding group counseling sessions, continually communicating with parents through sending thematic brochures on student learning practices. And ... one of the activities of Primary School is.

\section{Life Skills}

Life skills are personal and social skills that children and adolescents must learn to be effective, competent, and confident about themselves, other people, and the community as a whole. Teaching life skills lessons in Primary School is one of the main lessons in active learning. This is a group and collaborative activity based on student activities such as role playing, class discussion, sharing experiences and feelings, storytelling, poetry. And ... it is. 


\section{Extracurricular}

A happy and vibrant school environment creates an environment of educational excellence and nurtures students' thoughts and creativity. Primary School is a multidimensional school, providing educational enjoyment by providing activities that enhance and enhance classroom learning.

Every school and country has own strategy in better educating students. For example here is the strategies of Australian schools.

- Teacher Goals: Assist in learning and acquiring the skills necessary for practical student learning.

\section{Teamwork}

3. Wearing a uniform

4- Keep the class number as low as possible

5- 9am to 3pm Monday to Friday.

6. Teachers must have a university degree.

7. Foreign students must first take English courses

\section{Method}

\section{Research Model}

Interviews were used from the qualitative data collection methods in order to obtain the views of the preschool teacher candidates who take Special Teaching Method course. Consequently, a semi-structured interview form was designed to reveal the preschool teacher candidates determine towards the preference of methods. Eighty-seven preschool teacher candidates were interviewed using the semi-structured interview form. The data was then analysed by content analysis. In the analysis of the research data, categorization was made by coding and individual criticisms were also made based on the opinions of the teachers.

All school supplies at home should also be used Before you start studying, make sure you have all the supplies you need, for example, books, puzzles, diagrams, and writing supplies. If accessories are not available, you will have to get them up and down during the study, which will definitely disrupt the study. Make sure all the necessary tools are readily available. 


\section{Participants}

In the sample group of the research, the opinion interview was applied on the basis of volunteerism from the 87 preschool teacher candidates who took of the Special Teaching Method course taught in the Faculty of Education in the Turkish Republic of Northern Cyprus.

\section{Data Collection Instruments}

The researchers prepared a semi-structured interview form to reveal the preschool teacher candidates towards the methods which used in teaching process. Before applying the semi-structured interview form the pilot form of the interview form was finalised once the degree of understanding was examined.

\section{Data Collection}

The interviews conducted by telephone or face-to-face interview and appointment. Particular attention was given to ensure silence in the location where the interviews were held to ensure accurate voice recordings in the interviews with the preschool teacher candidates.

The following table depicts the goal of teaching and prerequisite for each teacher.

Table1. goals considered for each teachers

\begin{tabular}{|c|c|c|}
\hline Main goal & Goals & Strategies \\
\hline & $\begin{array}{l}\text { Creating a research platform } \\
\text { with trunks } \\
\text { Various research and specific } \\
\text { short and long term goals }\end{array}$ & $\begin{array}{c}\text { Formulate research priorities for a } 4 \text { year } \\
\text { period } \\
\text { - Developing the required workshops } \\
\text { program for faculty and students } \\
\text { For a } 4 \text { year period } \\
\text { Integrate student theses and align them } \\
\text { with the research goals of the group } \\
\text { - Conducting at least two research projects } \\
\text { with the Welfare, Municipal, and } \\
\text { International organizations such as } \\
\text { UNICEF in the next } 4 \text { years } \\
\text { - Increase in-group and out-group and } \\
\text { accreditation plans } \\
\text { - Publish at least } 2 \text { research articles or ISIs } \\
\text { per year by each member }\end{array}$ \\
\hline
\end{tabular}




\begin{tabular}{|c|c|c|}
\hline & & $\begin{array}{l}\text { - Participate in internal and external } \\
\text { seminars and conferences } \\
\text { - Collaborate with global organizations } \\
\text { such as UNESCO to improve the quality } \\
\text { of teaching and research and learn about } \\
\text { new achievements tailored to the } \\
\text { university's educational goals. } \\
\text { - Group site development } \\
\text { - Support and promote the preschool } \\
\text { student scientific community }\end{array}$ \\
\hline & Production and publishing & $\begin{array}{l}\text { - Follow-up to obtain a license and form a } \\
\text { journal of preschool education } \\
\text { - Perform fundamental and applied } \\
\text { research in the development and } \\
\text { education of preschool children } \\
\text { Standardize diagnostic and psychological } \\
\text { tests in the field of child development } \\
\text { - Translation and compilation of } \\
\text { educational resources on growth, } \\
\text { assessment, health, education, } \\
\text { management and planning of pre-school } \\
\text { education } \\
\text { - Holding an annual seminar on education } \\
\text { and health of young children } \\
\text { - Hold an international conference course } \\
\text { - Holding national and international } \\
\text { congresses and inviting keynote speakers } \\
\text { in the field of preschool children } \\
\text { - Holding theoretical preschool seats } \\
\text { every } 6 \text { months }\end{array}$ \\
\hline \multirow[t]{2}{*}{$\begin{array}{c}\text { Research } \\
\text { Objectives } \\
\text { And scholarship }\end{array}$} & $\begin{array}{l}\text { Improve and transform } \\
\text { Theoretical and practical } \\
\text { teaching }\end{array}$ & $\begin{array}{l}\text { - Conduct research on various teaching } \\
\text { methods by faculty members } \\
\text { - Use the educational spaces and } \\
\text { capacities of relevant organizations and } \\
\text { specialized NGOs for specialized courses } \\
\text { and internships and the presence of guest } \\
\text { professors } \\
\text { - International cooperation with world } \\
\text { universities in the field of pre-school }\end{array}$ \\
\hline & $\begin{array}{l}\text { Improvement and quality } \\
\text { improvement } \\
\text { Development of training } \\
\text { programs }\end{array}$ & $\begin{array}{l}\text { Outline the educational outlook of the } \\
\text { group for the next } 4 \text { years } \\
\text { - Approval and development of senior } \\
\text { majors from the Ministry of Science, } \\
\text { Health and the University of Applied } \\
\text { Sciences } \\
\text { - Scheduling and Managing Educational } \\
\text { Planning for Academic-Applied Courses } \\
\text { (Associate, Bachelor, Master) } \\
\text {-Collaborate with other educational } \\
\text { groups and research centers of the } \\
\text { university and domestic universities } \\
\text { - Increasing the ratio of faculty to students } \\
\text { Review of undergraduate courses }\end{array}$ \\
\hline
\end{tabular}




\begin{tabular}{|c|c|c|}
\hline & & $\begin{array}{l}\text { - Ordering and purchasing books related } \\
\text { to the field and developing specialized } \\
\text { group libraries } \\
\text {-Continuous collaboration of team } \\
\text { members with the University EDC Center } \\
\text { to empower faculty, revise undergraduate } \\
\text { programs and develop master's degrees } \\
\text { - Holding specialized workshops required } \\
\text { by students and faculty }\end{array}$ \\
\hline Educational goals & $\begin{array}{c}\text { Improvement of service quality } \\
\text { Training, counseling and } \\
\text { internships } \\
\text { Tailored to the needs of the } \\
\text { community } \\
\text { At the university level }\end{array}$ & $\begin{array}{l}\text { Expanding internships to government } \\
\text { agencies, the private sector, specialized } \\
\text { NGOs } \\
\text { - Scientific oversight of short-term } \\
\text { university courses } \\
\text {-Developing educational standards for } \\
\text { kindergartens } \\
\text { Effective presence of faculty members in } \\
\text { internship centers } \\
\text { - Hold specialized workshops for } \\
\text { preschool educators and administrators } \\
\text { Create an integrated system for recording } \\
\text { preschool children's studies and research } \\
\text { - Presence of faculty members in } \\
\text { university centers (family education } \\
\text { department) } \\
\text { - Liaising with social institutions and } \\
\text { requesting authoritative membership of } \\
\text { the said institutions in the Student } \\
\text { Scientific Association } \\
\text { - Attempts to get a job at the Ministry of } \\
\text { Health and Education for graduates }\end{array}$ \\
\hline Educational goals & $\begin{array}{c}\text { Development of spaces } \\
\text { Administrative and Educational } \\
\text { Department }\end{array}$ & $\begin{array}{c}\text { Extension of office space, workshop } \\
\text { (practical classes) and group laboratory } \\
\text { (Pediatric Psychological Examinations } \\
\text { Center) }\end{array}$ \\
\hline
\end{tabular}

\section{Data Analysis}

The descriptive analysis method was used for the pre-school teacher candidates' and interviews conducted to determine the Special Teaching Method course which compulsory course for all pre-school teacher candidates. In this study, content analysis used and data collected through interview technique. With content analysis themes and codes developed according to the interviews. The data obtained from interviews was of great significance while the code list was being generated. After the coding process extracted from the data obtained via the interviews, the codes obtained were collated and the themes were created. The code list and themes generated were finalized by consulting experts on qualitative research. The theme and 
codes obtained from the content analysis of the interviews are presented in a way that the reader can understand by providing direct citations.

\section{Results and Discussions}

Findings and comments obtained from the interview form for pre-school teacher candidates are given below.

The data obtained about the opinions of teachers on learning issues of the special teaching methods course are categorized under the themes and coded. The assessment of teaching issues is categorized under 3 groups; The conformity of teaching strategies, teaching methods, and the teaching techniques. The teachers' opinions related to the first theme were categorized under three different codes, the opinions on the second theme were categorized under five different codes, the opinions on the third theme were categorized under eight different codes.

Table 2. The pre-school teacher candidates' preferred teaching strategy methods and techniques in classroom activities

\begin{tabular}{|c|c|}
\hline Themes & Codes \\
\hline \multirow{4}{*}{ Teaching strategies } & Teaching through presentation \\
\cline { 2 - 2 } & Teaching through invention \\
\cline { 2 - 2 } & $\begin{array}{c}\text { Teaching through research- } \\
\text { investigation }\end{array}$ \\
\hline \multirow{4}{*}{ Teaching methods } & Micro-teaching \\
\cline { 2 - 2 } & Discussion \\
\cline { 2 - 2 } & Presentation \\
\cline { 2 - 2 } & Problem solving \\
\hline \multirow{5}{*}{ Teaching techniques } & Individual study \\
\cline { 2 - 2 } & Question-answer \\
\cline { 2 - 2 } & Drama \\
\cline { 2 - 2 } & Program-based teaching \\
\cline { 2 - 2 } & Computer supported teaching \\
\cline { 2 - 2 } & Observation \\
\cline { 2 - 2 } & Homework \\
\cline { 2 - 2 } & Project based teaching \\
\hline
\end{tabular}


Regarding the first theme which focuses on "teaching strategies", pre-school teacher candidates put forth that the teaching strategies were not used in coherence throughout the special teaching methods course. Some statements made by pre-school teacher candidates on this issue are as follows:

"The teaching strategies, method and techniques used throughout the teachinglearning process are in line with the objectives, however, I only use the presentation strategy in the classroom." (Pre-School Teacher Candidate, 16)

"I am the one presenting and developing the materials for the lesson. I cannot give research tasks to my classmates to be more active participation." (Pre-School Teacher Candidate, 36)

"I cannot carry out research-investigation activities." (Pre-School Teacher Candidate, 12)

The opinions of teachers regarding the teaching strategies during special teaching methods course reveal that although the teaching strategies are required to be in line with the course objectives, if they are not and only the presentation strategy is used. This indicates that there are some insufficiencies for pre-school teacher candidates. It means that pre-school teacher candidates who are not well educated may also fail in their professional lives.

Through the second theme, pre-school teacher candidates' preference about the "teaching methods" that considered to be the most convenient in order to achieve the course objectives are not used throughout the teaching-learning process. Sample statements the teaching methods and course objectives are given below:

"I use the straight presentation method, which is the traditional method, in special teaching methods course, and from time to time, I use question-answer methods." (Pre-School Teacher Candidate, 22)

"The method I use while teaching the course is such that the students can establish the links between past, today and future. I instruct and guide my students to think, interpret and criticise." (Pre-School Teacher Candidate, 1)

Despite the fact that micro-teaching implies successfully. Another important finding is that the teacher candidates mostly use individual study methods, conduct case study and problem solving methods. On the contrary, if the studies are carried out in coherence with the program objectives and the course content is delivered to the students, then the students creative skills should develop (Kandemir, 2016; Keskin, 2009). Baykara (2013) stated that thinking skills of most of the students develop due to the use of correct materials by teachers. Under the 
light of these findings, it could be suggested that there are some insufficiencies in learning issues related to pedagogical teacher training courses during the teaching-learning process.

In the third theme focusing on "teaching techniques". A sample statement related to the coherence of the teaching techniques and course objectives is given below:

"Neither intramural activities, nor extramural activities; exploration trips, visits to museums and historical and cultural places cannot be performed." (Teacher, 82)

The data obtained from sample group about the coherence of teaching techniques which preferred by pre-school teacher candidates mostly question-answer technique and the group presentation technique. Pre-school teacher candidates also stated that they never use the individualized teaching, programmed teaching, computer assisted teaching and extramural teaching techniques such as field trips, observation, exhibition, projects, homework studies, interviews. Apart from these, pre-school teacher candidates came up with negative opinions about the coherence of teaching techniques and course objectives, which are required to be taught throughout the course. Kandemir (2016) stated that although included in the course content, there are no opportunities to develop students' creative skills and, moreover, the school environment and conditions are not suitable to use the required techniques by the students. Besides, time limitations and lack of knowledge on the subjects, which must be taught, also cause a negative impact on teaching-learning process. Thus, students' skills cannot be developed. Under the light of these findings, it could be put drama techniques, mostly used teaching-learning process.

Children between the ages of 1 and 2 make great progress. Children enter childhood as children at the age of six. They have great creativity, they may have a lot of fear, and they like to play physically. As they get older from age 2 to age 2, they become more confident and independent about trying new things. Throughout these ages, the development of language and knowledge has changed dramatically, from asking questions to frequently asked questions so that they can tell their story sequentially and enjoy jokes and riddles. Whatever role you play in a child's life (teacher, parent, or other caregiver), there are ways to make the education of children more effective, fun, and enjoyable for both of you.

Read for children

Reading aloud to children is highly recommended since it is recognized as the most important activity in language development. This creates the awareness of sound and speech 
that is expected to improve very well in the future. It also creates motivation and curiosity, reinforces memory and, of course, acquainted with different words. When children have a good experience of books at an early age, they are more likely to continue this enjoyable feeling and self-confidence in life-long study.

Find picture books for younger ages (1-4) and let kids stop reading and ask questions or talk about the book while reading.

Keep books of different ages and attractions around the house or class to enhance children's reading ability. Ask them what they like to study and make that type of book available.

Continue reading aloud to older children; these books are always good for them! Every night before bedtime, or after school is the best time to do this activity

\section{Playing game}

Playing aunt or other fantasy games is very important for creativity as well as social relationships and language development and children's education. They love nothing more than to enter their fantasy world.

Sometimes imitate their activities. If the child picked up a stone and quickly moved it like a car, you would take one stone and do the same. They will probably be happy.

A box full of empty boxes, old clothes and hats, handbags, phones and magazines (never broken) kitchen utensils and utensils, animal toys and dolls, pieces of cloth or blankets and sheets (For the castle) and other things like postcards, old tickets, coins, etc., and pretend you're playing at home or in class.

\section{Do the artwork and crafts}

Painting, painting and crafts are not only a great way to keep children on a rainy day, but they also help develop children's motor skills, develop color concepts and numbers, and help them in scientific processes such as Knows the function of the adhesive. Remember to use tools of different ages, such as baby scissors.

For younger children, make dolls, jewelry pasta.

Older children usually like colored magazines, pottery and mask making. 
Have an art center at home or in class where you can hold paper, mags, candles, colored pencils, scissors, glue and other tools such as wool, foam, pipe cleaners, paper towels, and more.

\section{Songs and songs are effective in educating children}

Music has long been associated with the development of mathematical thinking. Listening to rhythms and counting beats improves math skills, as well as listening to words in song improves language skills. Children also often use music to improve their physical skills because they like to dance, dance, dance and dance while playing music.

Sing to the young children songs with a childlike rhythm. They love simple and repetitive songs, and they learn to sing with you.

Find kids' favorite songs on CDs or the Internet and play at home or in class for the time being.

Older children (1-5) may have a particular interest in an instrument or singer or dancer. If they have an interest, try reinforcing their interest with their own beginner instruments or lessons with a music instructor (either singing or dancing).

5. Play sports together

Even if you are not a sports enthusiast, getting to know and playing with children is important for their physical development and motor skills. Exercise also teaches honesty, teamwork, fair play, respect for the rules and respect for yourself and others.

Choose the one or two sports that you sometimes play with your kids and provide the necessary things to play. For example, get a basketball and find the neighborhood basketball court you can go to, or get a baseball, gloves and a hat and try to play a local game.

If you are a classroom teacher, encourage them to exercise by providing exercise equipment for the buzzer, asking about their play and watching them play at school or at local stadiums.

\section{Discussion and Conclusion}

When pre-school teacher candidates were asked the most preferred methods and techniques within the scope of special teaching methods course, "drama came to the forefront 
with both the method and the technique, and it was emphasized that the drama allowed the student to activate the spontaneous functioning of the drama.

With the drama technique, it is pointed out that students can improve their problem solving and communication skills while learning how to behave in which situations. The most important of the benefits to be obtained by performing all stages of the method in a controlled manner (Özden, 2000); The difficulty in the narration is to make it easier to express the relatively abstract subjects and to develop their self-confidence and to develop themselves through different roles. Drama is defined as the act of meaning by certain people rather than random people doing something by chance. It includes all activities that involve action within drama. These activities include individuals 'communication with each other, individuals' communication with different objects and actions that arise as a result of reactions (Bulut $\&$ ve Aktepe, 2015; Ulubey \& Toraman, 2015). Uşaklı (2014) emphasizes that there are two basic elements of drama. One of them is human and the other is action. In other words, drama describes the people in action. San (2014) emphasized the concept of play in drama and considered play as the main element of creative drama. San (2014) also emphasizes that one of the most important goals of creative drama is social learning and socialization.

As a suggestion for this research is the fact that preschool teacher candidates are aware of the importance of teaching strategies, methods and techniques becomes even more important considering that they can transfer these strategies to their students. Therefore, it is important to give the necessary importance to the courses related to teaching strategies.

\section{REFERENCES}

1. Aksu, G., \& Doğan, N. (2015). Öğretim Yöntem ve Tekniklerinin Öğrenci Görüşlerine Göre İkili Karşılaştırma Yöntemiyle Ölçeklenmesi. Eğitimde ve Psikolojide Ölçme ve Değerlendirme Dergisi, 6(2), 194-206

2. Açıkgöz, K. (1998). Etkili öğrenme ve öğretme. İzmir: Kanyılmaz Matbaası.

3. Baykara, K. (2013). İçeriğin ve eğitim durumlarının düzenlenmesi. H. Şeker (Ed.), Eğitimde program geliştirme kavramlar yaklaşımlar (ss.164-182). Ankara: Anı Yayıncılık.

4. Bulut, A., \& ve Aktepe, V. (2015). Yaratıcı Drama Destekli Matematik Öğretimin.

5. Öğrencilerin Akademik Başarısına Etkisi. Kastamonu Üniversitesi Kastamonu Eğitim Dergisi, 23(3), 1081-1090.

6. Covill, A. (2011). College Students Perceptions of the Traditional Lecture Method. College Student Journal, 45(1), 2-15.

7. Kahyaoğlu, M., \& Yangın, S. (2007). İlköğretim Öğretmen Adaylarının Mesleki Öz Yeterliklerine İlişkin Görüşleri. Kastamonu Eğitim Dergisi, 15, 83-105. 
8. Kandemir, A. (2016). İlkokul 2. sınıf İngilizce öğretim programının katılımcı odaklı program değerlendirme yaklaşımıyla değerlendirilmesi (Yayımlanmamış Yüksek Lisans Tezi). Pamukkale Üniversitesi, Denizli.

9. Keskin, A. (2009). İlköğretim düşünme eğitimi dersi (6., 7., ve 8. sınıf) Öğretim Programının değerlendirilmesi. (Yayımlanmamış Yüksek Lisans Tezi). Mustafa Kemal Üniversitesi, Sosyal Bilimler Enstitüsü, İlköğretim Anabilim Dalı, Hatay.

10. Marbach, G., Seal, O., \& Sokolove, P. (2001). Student Attitudes and Recommendations On Active learning, Journal of College Science Teaching, JO, 434-438.

11. Özden, Y. (2000). Öğrenme ve Öğretmen, Pegem A Yayınc1lık, Ankara.

12. Öztürk, B. (1996). Genel öğrenme stratejilerinin öğrenciler tarafindan kullanma durumları. Marmara Üniversitesi Atatürk Eğitim Fakültesi İkinci Ulusal Eğitim Sempozumu Bildirileri. İstanbul, 239-244.

13. Saban, A. (2004) Öğrenme Öğretmen Süreci Yeni Teori ve Yaklaşımlar, Nobel Yayınevi, Ankara.

14. San, 1. (1990). Eğitimde Yaratıcı Drama. Ankara Üniversitesi Eğitim Bilimleri Fakültesi Dergisi, 23(2), 573-582.

15. Ulubey, Ö., \& ve Toraman, Ç. (2015). Yaratıcı Drama Yöntemının Akademık Başarıya Etkısı: Bır Meta-Analız Çalışması. Mustafa Kemal Üniversitesi Sosyal Bilimler Enstitüsü Dergisi. Cilt:12, Say1: 32.

16. Uşaklı, H. (2014). Drama ve İletişim Becerileri Teori, Araştırma, Uygulama. (3.Baskı) Nobel Yayıncilık.

\section{SOBRE OS AUTORES:}

\section{Ípek Danju}

Near East University, Atatürk Faculty of Education, Department of Educational Programs and Instruction, Nicosia, North Cyprus, Mersin 10, Turkey, Postal Code: 922022. E-mail: ipek.danju@neu.edu.tr

iD http://orcid.org/0000-0003-1738-5261

\section{Seçil Besim}

Near East University, Atatürk Faculty of Education, Department of Educational Programs and Instruction, Nicosia, North Cyprus, Mersin 10, Turkey, Postal Code: 922022. E-mail: secil.besim@neu.edu.tr

iD http://orcid.org/0000-0002-2949-4660

Recebido em: 19 de novembro de 2019 Aprovado em: 07 de dezembro de 2019

Publicado em: 20 de janeiro de 2020 